TERMINUS

t. 21 (2019), z. 1 (50), s. 105-140

doi:10.4467/20843844TE.19.005.10505

www.ejournals.eu/Terminus

http://orcid.org/0000-0002-1714-0179

Justyna Gałuszka

Uniwersytet Jagielloński, Kraków

justyna.galuszka@uj.edu.pl

\title{
Mowy Jakuba Sobieskiego na pogrzebach Stanisława, Jana i Reginy Żółkiewskich jako przykład oratorstwa siedemnastowiecznego - edycja źródłowa
}

\begin{abstract}
Jakub Sobieski's Speech at the Funerals of Stanisław, Jan and Regina Żółkiewski as an Example of $17^{\text {th }}$-Century Oratory - Source Edition
\end{abstract}

The $17^{\text {th }}$-century funeral ceremonies included occasional speeches given by a close relative, friend, or acquaintance, which supplemented the preachers' sermons. The paper is a discussion and critical source edition of Jakub Sobieski's (1590-1646) speeches on three representatives of the Żółkiewski family: Stanisław (1547-1620), Jan (d. 1623), and Regina (1566-1624). Sobieski was considered one of the best orators of his time. He was often invited to various events, which he honoured with his speeches. Those delivered at Żółkiewskis' funerals strike with their depth and show the tragedy of this family, but at the same time they display Sobieski's oratorical skills, education, and erudition. They also emphasize the genealogical relations between the Sobieski and Żółkiewski families. They capture a portrait of a tragic family: an image of a great hetman, who heroically defended his homeland in advanced age, a son who imitated the actions of his father, and a virtuous mother and wife-three models worthy of distinction and praise.

Keywords: old-Polish funeral, funeral speeches, Jakub Sobieski, Stanisław Żółkiewski, critical source edition 
Wiek XVII, który określić można jako „renesans śmierci”, przyniósł rozbudowę uroczystości funeralnych, którym towarzyszyły zarówno kazania, jak i świeckie oracje. Jednym $\mathrm{z}$ najznakomitszych mówców tej epoki był Jakub Sobieski (1590-1646), ojciec przyszłego polskiego monarchy. Jego kariera jest wręcz modelowym przykładem budowania świetności i znaczenia rodu. Sobieski wywodził się ze średniozamożnej szlachty czerwonoruskiej. Urodził się prawdopodobnie w 1590 roku jako syn Marka i Jadwigi ze Snopkowskich. Niewiele wiadomo o jego młodzieńczych latach poza tym, że studiował w Akademii Zamoyskiej i Akademii Krakowskiej. Wykształcenie uzupełniał poza granicami Rzeczypospolitej. Od 1607 roku podróżował po Europie Zachodniej, o czym dokładnie pisał w swoich pamiętnikach, wydanych dopiero w 1991 roku przez Józefa Długosza. Dzięki tej podróży poznał obce języki, między innymi francuski, włoski i hiszpański, uczył się także przydatnych szlacheckiemu młodzieńcowi umiejętności: jazdy konnej, tańca i władania bronią. Po powrocie do kraju w 1613 roku był już wykształconym młodym człowiekiem o szerokich horyzontach światopoglądowych. Od tego momentu rozpoczęła się także jego kariera parlamentarna, podczas której pełnił funkcję marszałka izby poselskiej, wielokrotnie był też wybierany na posła $\mathrm{z}$ województwa ruskiego.

W poprzedzającym edycję źródłową artykule chciałabym przedstawić tło historyczne dla części mów Sobieskiego, poświęconych przedstawicielom rodu Żółkiewskich: Reginie, Stanisławowi i Janowi, które zostały wygłoszone podczas ich uroczystości pogrzebowych. Badacze życia i twórczości Sobieskiego uważali je za jedne z najpiękniejszych. Sobieski miał już doświadczenie retoryczne: wielokrotnie przemawiał na uroczystościach państwowych i prywatnych, stąd nazywano go polskim Demostenesem² ${ }^{2}$ Współcześnie

${ }^{1}$ Sformułowanie zaczerpnięte z: J. Kolbuszewski, Kryzys, pornografia i renesans śmierci, w: idem, Problemy wspótczesnej tanatologii, Wrocław 1997, s. 7-16.

2 J. Sobieski, Peregrynacja po Europie (1607-1613). Droga do Baden (1638), wyd. J. Długosz, Wrocław 1991, s. 7. 
jego oracje również budzą zachwyt stylem i wyszukaną polszczyzną. Wybrane przeze mnie mowy po raz pierwszy zostały wydrukowane w zbiorze Jana Pisarskiego, księgarza i tytularnego sekretarza króla Jana III Sobieskiego, w 1668 roku (drugi tom wydano w 1676 r.) ${ }^{3}$. Korzystam z wydania z 1683 roku przechowywanego w Bibliotece Jagiellońskiej. Zbiór ten Maria Barłowska uważa za „punkt zwrotny w dziejach polskiego oratorstwa"4. Ojciec przyszłego króla został przez wydawcę szczególnie wyróżniony, ponieważ w jego zamyśle przewodził on sarmackiemu kręgowi oratorów, o czym świadczy chociażby umieszczenie we wspomnianej antologii aż siedemnastu mów Jakuba. To oczywiście nie oddaje w pełni ogromnej liczby jego oracji znanych nam współcześnie. Był to najobszerniejszy spośród wydanych w XVII wieku zbiorów oratorskich, powstałych „do głośnej wieków potomnych pamięci”' Jak stwierdził Bogdan Rok, podsumowując swoje badania druków żałobnych okresu staropolskiego, owe zbiory były najpopularniejszą formą utrwalania takich utworów ${ }^{6}$. Antologia Pisarskiego stanowi wzór sarmackiej wymowy, ponieważ zawiera przykłady godne naśladowania i upowszechniania ${ }^{7}$.

Wybrane przeze mnie mowy nie były przedmiotem osobnych studiów, jedynie Zofia Trawicka przedstawiła ich ogólny wydźwięk w tekście poświęconym mowom weselnym i pogrzebowym Jakuba

3 J. Sójka, Pisarski Jan Stefan hr. Szreniawa (ok. 1630-1678), w: Polski słownik biograficzny, t. 26, Wrocław 1981, s. 549.

4 M. Barłowska, Swada i milczenie. Zbiory oratorskie XVII-XVIII wieku prolegomena filologiczne, Katowice 2010, s. 282.

${ }^{5}$ Mówca polski, albo wielkich senatorów powaga i ojczystą wymową oratorów sejmowe i pogrzebne mowy do głośnej wieków potomnych pamięci podane, [ed. J. Pisarski], t. 1, wyd. 2, Kalisz: Kole<g>ium Societatis Iesu, 1683 (odbicie B, egz. Biblioteki Jagiellońskiej, sygn. 19621 I).

${ }^{6}$ B. Rok, Druki żałobne $w$ dawnej Polsce XVI-XVIII w., w: Wesela, chrzciny i pogrzeby w XVI-XVIII wieku. Kultura życia i śmierci, red. H. Suchojad, Warszawa 2001, s. 199.

7 M. Barłowska, Swada i milczenie..., s. 284. 
Sobieskiego ${ }^{8}$. Tworzą one swoisty portret rodzinny, podkreślają równocześnie związki rodzinne Żółkiewskich i Sobieskich, co służyło wzmocnieniu propagandowego wizerunku króla Jana III Sobieskiego - wodza i hetmana. Na zawsze zostały w nich utrwalone obrazy wielkiego hetmana, bohatersko broniącego ojczyzny w sędziwym wieku, syna naśladującego czyny ojca i cnotliwej białogłowy, razem trzy wzorce godne wyróżnienia i pochwały. Warto również podkreślić, że choć przemawianie na pogrzebach stanowiło nieodłączny element kultury Rzeczypospolitej szlacheckiej, to już ogłaszanie mów pogrzebowych drukiem należało do rzadkości. Najczęściej gromadzono je w sylwach jako dokumenty rodzinne i wzory oratorstwa ${ }^{9}$. Zapewne mowy „polskiego Demostenesa” znalazły poczesne miejsce w zbiorze Pisarskiego dzięki estymie, jaką swojego ojca darzył Jan III Sobieski ze względu na jego zasługi żołnierskie i służbę publiczną ${ }^{10}$.

Dorobek oratorski Jakuba Sobieskiego nie doczekał się do tej pory całościowego opracowania. Wybrane przeze mnie mowy są ważne również dlatego, że są rzadkim przykładem podziękowań na pogrzebach i stanowią odrębny tekst. Zazwyczaj tego typu mowy funkcjonowały jako ostatnia część kazania pogrzebowego ${ }^{11}$. W przypadku mów na pogrzebach członków rodziny Żółkiewskich mamy do czynienia z połączeniem mowy pogrzebowej i podziękowania, które dowodziło nie tylko przyjaźni dla zmarłego, ale było też spełnieniem chrześcijańskiej powinności ${ }^{12}$. Należy mieć jednak na uwa-

8 Z. Trawicka, Mowy weselne i pogrzebowe Jakuba Sobieskiego, w: Wesela, chrzciny..., s. 173-186; eadem, Jakub Sobieski 1591-1646. Studium z dziejów warstwy magnackiej w Polsce doby Wazów, Kraków 2007.

${ }_{9}$ M. Barłowska, Jakub Sobieski pamięci wielkiego kawalera Bartłomieja Nowodworskiego, Szczecin 2006, s. XLI-XLII.

${ }_{10}$ Pisma do wieku i spraw Jana Sobieskiego, t. 1, cz. 1, wyd. F. Kluczycki, Kraków 1880, s. 2.

${ }^{11}$ M. Skwara, Polskie drukowane oracje pogrzebowe XVII wieku. Bibliografia, Gdańsk 2009, s. 83.

${ }^{12}$ O oracjach pogrzebowych szerzej między innymi: M. Barłowska, Ossoliński, Moskorzowski, Sarbiewski - mowy pogrzebowe. Teksty $w$ dialogu, Katowice 2008; eadem, O badaniu staropolskiego oratorstwa (na przykładzie świeckiego oratorstwa 
dze, że z jednej strony druk tych utworów stanowił także przejaw chęci ich ocalenia i rozpowszechnienia $w$ tej formie, $z$ drugiej zaś że jest to jedynie zapis tekstu, który w swojej pierwotnej formie funkcjonował jako bardzo istotny element kultury żywego słowa, tak charakterystycznej dla ówczesnej Rzeczypospolitej. Nie daje on możliwości odtworzenia atmosfery uroczystości, reakcji uczestników na wypowiadane słowa, mimikę i gestykulację oratora ${ }^{13}$.

Warto również przypomnieć, jak w epoce staropolskiej przebiegał pogrzeb - swoiste widowisko łączące słowo i obraz w jeden uroczysty spektakl. O scenariuszu całej ceremonii decydowała liturgia opisana w stosowanym od 1631 roku rytuale, opracowanym na soborze trydenckim $^{14}$. Ważne miejsce w czasie tych uroczystości zajmowały kazania i mowy okolicznościowe. Pierwsze z nich niekiedy bywały sprzeczne w swojej wymowie, upamiętniającej zmarłego, z głównymi celami kazań, czyli pouczeniem, napomnieniem i pobudzeniem do cnoty ${ }^{15}$. Oratorzy świeccy nie byli w ten sposób ograniczani - ich głównym celem było zachowanie pamięci o tym, który odszedł z tego świata.

Życie, działalność i tragiczna śmierć kanclerza oraz hetmana wielkiego koronnego Stanisława Żółkiewskiego (1547-1620) wzbudzały zainteresowanie wielu pokoleń historyków ${ }^{16}$. Nie będę tu omawiać

epoki baroku), w: Retoryka w Polsce. Teoria i praktyka w ostatnim półwieczu, red. M. Skwara, Szczecin 2006, s. 75-93; U. Kicińska, Wzorzec szlachcianki w polskich drukowanych oracjach pogrzebowych XVII wieku, Warszawa 2013; A. Nowicka-Struska, Elementy teatralne, gest $i$ komunikacja niewerbalna $w$ siedemnastowiecznych kazaniach pogrzebowych, „Annales Universitatis Mariae Curie-Skłodowska. Sectio FF, Philologiae" 24 (2006), s. 71-97.

${ }_{13}$ M. Barłowska, Jakub Sobieski..., s. XLVI.

14 A. Labudda, Liturgia pogrzebu w Polsce do wydania Rytuału Piotrkowskiego (1631). Studium historyczno-liturgiczne, Warszawa 1983.

${ }^{15} \mathrm{~J}$. Niedźwiedź, Nieśmiertelne teatra sławy. Teoria i praktyka twórczości panegirycznej na Litwie w XVII-XVIII w., Kraków 2003, s. 254-270.

${ }^{16}$ Jego biografami byli między innymi: A. Prochaska, Hetman Stanisław Żółkiewski, Warszawa 1927; K. Tyszkowski, Hetman Stanisław Żółkiewski, Lwów 1927; L. Podhorodecki, Hetman Żółkiewski, Warszawa 1968; idem, Wielki hetman Rzeczypospolitej. Opowieść o Stanisławie Żółkiewskim, Warszawa 1987; J. Besala, Stanisław 
szerokiej działalności hetmana, przedstawię jedynie ostatnie chwile jego życia, śmierć i pogrzeb. Sądzę jednak, że należy zarysować tło polityczne wydarzeń, które doprowadziły do śmierci hetmana.

Koniec drugiej dekady XVII wieku upływał pod znakiem dużego napięcia w stosunkach pomiędzy Rzecząpospolitą polsko-litewską a Portą Otomańską. Składało się na to kilka czynników, do których możemy zaliczyć między innymi łupieżcze wyprawy Kozaków aż pod sam Konstantynopol, ścieranie się wpływów polskich i tureckich na terenie Mołdawii oraz Wołoszczyzny, prohabsburską politykę Zygmunta III Wazy, wreszcie najazdy tatarskie na ziemie Rzeczypospolitej. Hetman przewidywał, że wojna jest nieunikniona, dlatego starał się mobilizować szlachtę do wysiłku finansowego i wystawienia armii broniącej granicy południowej. W czerwcu 1620 roku pisał do prymasa królestwa Wawrzyńca Gembickiego, że nie ma już żadnej nadziei na utrzymanie pokoju z Turcją ${ }^{17}$. Latem tego samego roku do Warszawy powrócił poseł Rzeczypospolitej do Turcji, Samuel Otwinowski, który przywiózł ze Stambułu wiadomość o wypowiedzeniu wojny przez sułtana ${ }^{18}$. W lipcu podjęto decyzję o wyprawie wojennej, której celem miało być wyjście na spotkanie armii turecko-tatarskiej i wkroczenie do Mołdawii. Żółkiewski liczył na wsparcie tamtejszego hospodara, Kaspra Grazianiego ${ }^{19}$. Przed przekroczeniem granicy hetman napisał do króla list, w którym dał wyraz swojemu ogromnemu zmęczeniu zarówno fizycznemu, jak i psychicznemu. Wyra-

Żółkiewski, Warszawa 1988. W ostatnich latach najwięcej uwagi poświęca tej postaci Jerzy Urwanowicz, zob. J. Urwanowicz, Stanisław Żółkiewski wobec Moskwy. Koncepcje i działania, w: Polska wobec wielkich konfliktów w Europie nowożytnej. Z dziejów dyplomacji i stosunków międzynarodowych w XV-XVIII wieku, red. R. Skowron, Kraków 2009, s. 49-64; J. Urwanowicz, „Początek i progres wojny moskiewskiej”, czyli o Stanisława Żółkiewskiego „ochocie do służenia królowi jegomości Rzeczypospolitej”, „Białostockie Teki Historyczne” 9 (2011), s. 55-65.

17 S. Żółkiewski do W. Gembickiego z Żółkwie 20 VI 1620, w: Pisma Stanisława Żółkiewskiego kanclerza koronnego i hetmana. Z jego popiersiem, wyd. A. Bielowski, Lwów 1861, s. 372-374.

18 J. Besala, Stanisław Żółkiewski, s. 351.

19 Ibidem, s. 352. 
żał również szczerą troskę o losy kraju oraz uświadamiał władcy, że „wojna z Turki nie igraszka; albo Turki trzeba zrazić z ich przedsięwzięcia, którzy chcą tej Rzeczypospolitej i wszystkiemu światu panować, albo tobie królestwo stracić"20.

Hetman zamierzał nie dopuścić do połączenia się sił tureckich i tatarskich, jednak nie miał wystarczającej pomocy ze strony Kozaków zaporoskich oraz Grazianiego ${ }^{21}$. Nie znał dokładnie sytuacji politycznej w Mołdawii, więc postanowił udać się do Cecory, gdzie znajdowały się fortyfikacje pamiętające jeszcze wyprawę poprzedniego kanclerza i hetmana wielkiego koronnego, Jana Zamoyskiego, z 1595 roku. Wkrótce pod Cecorę nadciągnęły wojska osmańskie i tatarskie. Początkowo z powodzeniem odpierano ich ataki, jednak 19 września w wyniku kolejnego starcia hetman stracił część ludzi, wozów i sprzętu. Pomysł Żółkiewskiego, aby następnego dnia ponowić atak, nie spotkał się z przychylnym przyjęciem pozostałych dowódców (m.in. Samuela Koreckiego - pułkownika i dowódcy lewego skrzydła w bitwie cecorskiej ${ }^{22}$ ). Zdecydowano się na odwrót, lecz wojsko, obserwując ucieczkę części dowództwa, wszczęło bunt, który groził całkowitym chaosem w obozie. Hetmanowi udało się zażegnać niebezpieczeństwo i uspokoić żołnierzy. Fiaskiem zakończyła się próba podjęcia rokowań z Turkami, ale pozwoliło to na przygotowanie taboru do odwrotu, który nastąpił 29 września. Aż do 7 października armia posuwała się w kierunku granicy Rzeczypospolitej, lecz tego dnia nieopodal Dniestru w szeregach wojska ponownie wybuchł bunt, którego nie udało się już opanować. Atakowani przez Tatarów żołnierze rzucili się masowo do ucieczki. Sam hetman zginął, następnego dnia jego ciało z odciętą prawą ręką oraz głęboką raną na głowie znaleźli Turcy. Ciało pozbawiono głowy, która została zawieszona nad wejściem do

20 S. Żółkiewski do Zygmunta III Wazy z Baru 26 VIII 1620, w: Pisma..., s. 375.

${ }^{21}$ Opis bitwy i tragicznego w skutkach odwrotu odtwarzam na podstawie: R. Majewski, Cecora. Rok 1620, Warszawa 1970, s. 180-223.

${ }^{22}$ J. Maciszewski, Samuel Korecki hr. Pogoń (ok. 1586-1622), Polski słownik biograficzny, t. 14, Wrocław 1968-1969, s. 60-62. 
pałacu sułtańskiego Topkapi w Stambule ${ }^{23}$, zaś pozostałe szczątki odnaleźli później wysłannicy Reginy Żółkiewskiej². Wokół tej tragicznej śmierci narosło wiele mitów, różnie też oceniano zachowanie sędziwego hetmana podczas bitwy. Część historyków widziała w nim odważnego bohatera, inni sugerowali, że rezygnując z ucieczki, celowo chciał poświęcić swoje życie za ojczyznę $e^{25}$. Nikłe są szanse jednoznacznego rozwiązania tej zagadki, zapewne prawda leży pośrodku. Żółkiewski chyba przeczuwał nadchodzącą śmierć, czemu dał wyraz w liście do małżonki, pisanym w wigilię dramatycznych wydarzeń, jednocześnie odniesione rany sugerują, że walczył mężnie do końca ${ }^{26}$.

Pod koniec października Rzeczpospolitą obiegła informacja o tragicznej śmierci Żółkiewskiego. Ciało pozbawione głowy przywieziono do Baru, o czym poinformowano w połowie miesiąca wojewodę kijowskiego Tomasza Zamoyskiego ${ }^{27}$. Około 19 października wiadomość przekazano królowi; wieść o klęsce i śmierci wodza miała wywołać u niego silne wzruszenie i łzy ${ }^{28}$. Pogrzeb hetmana odbył się 16 listopada 1621 roku w Żółkwi. Wskazówki dotyczące jego przebiegu podał sam Żółkiewski w spisanym pod Cecorą akcie swej ostatniej woli. Miała to być skromna uroczystość, pozbawiona ostentacji i przepychu, ciało winno być pochowane w ufundowanej przez zmarłego kolegiacie św. Wawrzyńca w Żółkwi ${ }^{29}$. Gdyby

23 J. Besala, Stanisław Żółkiewski, s. 367.

${ }^{24}$ Wyprawa cecorska, Biblioteka Naukowa Polskiej Akademii Umiejętności i Polskiej Akademii Nauk w Krakowie, nr 1052, s. 94. Ciekawą relację o tej wyprawie stanowi List od P. Jazkowskiego do P. podkomorzego bełskiego po ostatnim rozgromieniu taboru wojska naszego w Wołoszech, nie daleko za Dniestrem de data Boryssowa 24 Octrobris 1620, Biblioteka Jagiellońska, sygn. 110, k. 36v.-39v.

${ }_{25}$ Zob. szerzej: R. Majewski, Cecora..., s. 217-218.

${ }^{26}$ S. Żółkiewski do R. Żółkiewskiej z obozu pod Cecorą 6 X 1620, w: Pisma..., s. 381-382.

27 S. Żurkowski, Żywot Tomasza Zamojskiego kanclerza wielkiego koronnego, Lwów 1860, s. 48.

28 A.S. Radziwiłł, Rys panowania Zygmunta III, wyd. J. Byliński, W. Kaczorowski, Opole 2011, s. 72.

29 Testament B, w: Pisma..., s. 290. 
hetman zginął, służąc ojczyźnie, jego trumnę miała przykrywać szkarłatna tkanina "na znak wylania krwie dla Rzeczypospolitej”30. Nagrobek winien być skromny, a wybitny polski poeta Szymon Szymonowic miał służyć radą w kwestii słów na nim wyrytych. Hetman zalecał, aby w miejscu jego śmierci usypano „kopiec Rzeczypospolitej granic"31 na pamiątkę przyszłych pokoleń ${ }^{32}$.

Mowa wygłoszona w kolegiacie żółkiewskiej przez Sobieskiego uderza swoim niewątpliwym kunsztem. Pełna jest rozbudowanych metafor, amplifikacji, antytez i aluzji do kultury antycznej. Liczne środki stylistyczne nie tylko ukazują potęgę śmierci i żal po odejściu zmarłego, ale przede wszystkim podkreślają jego zasługi dla kraju - nawet zwykłe podziękowania dla uczestników uroczystości i zaproszenie na stypę stały się okazją do laudacji zmarłego ${ }^{33}$. Autor wielokrotnie odwołuje się do Boga i Ojczyzny, co zapewne miało skłonić słuchaczy do refleksji nad poniesioną stratą. Sobieski przedstawia historię życia tragicznie zmarłego w podeszłym wieku hetmana. Zaznacza, że ta śmierć za ojczyznę i wiarę katolicką zasługuje na pochwałę również dlatego, że Żółkiewski zdecydował się na wyprawę wojenną w wieku, w którym większość osób szuka odpoczynku i spokoju w domu wśród rodziny. Podkreślone zostało oddanie bohatera sprawom państwowym, wierna służba królom Stefanowi Batoremu i Zygmuntowi III pod kierunkiem mentora, kanclerza i hetmana wielkiego koronnego Jana Zamoyskiego. Zmarły nie uchylał się od obowiązków względem panujących i kraju - brał udział w licznych kampaniach wojennych i ekspedycjach: moskiewskiej (1577-1582), byczyńskiej, inflanckiej, wołoskiej, kolejnej moskiewskiej (1609-1618), rozprawiał się również z buntami kozackimi i starał się powstrzymać najazdy tatarskie. Sobieski podkreślił lojalność

30 Testament A, w: Pisma..., s. 179.

31 Testament B, s. 290.

32 Pomnik ten został zniszczony w 1898 roku, zob. J. Besala, Stanisław Żółkiewski, s. 367.

${ }^{33}$ M. Barłowska, Na swady sarmackiej placu. O kulturze oratorskiej wieku XVII, Kielce 2001, s. 60-61. 
Żółkiewskiego i jego oddanie Zygmuntowi III - to po jego stronie opowiedział się w czasie wojny domowej w pierwszej dekadzie XVII stulecia i „koronę już mu z głowy nachyloną utwierdził”34.

Niespełna dwa lata później (29 maja 1623 r.) odbył się pogrzeb jedynego syna Stanisława i Reginy, Jana, starosty hrubieszowskiego. Wtedy też pochowano głowę hetmana, wykupioną z rąk tureckich przez wdowę. Niewiele wiemy o życiu i działalności hetmańskiego potomka. Jedynie z listów i testamentów rodziców oraz jego własnej korespondencji (m.in. z Tomaszem Zamoyskim, przyjacielem i towarzyszem nauki) możemy czerpać pewne informacje. W obu wspominanych już testamentach hetman i kanclerz wielki koronny przejawiał wielką troskę o wychowanie syna ${ }^{35}$. Zwracał się do niego $\mathrm{w}$ tych dokumentach $\mathrm{w}$ sposób bezpośredni, zalecając mu szczególnie starania o zdobycie jak najlepszego wykształcenia, miłość do ojczyzny oraz poszanowanie jej praw. Refleksje te nie tylko przepełnione były wskazówkami dla Jana, ale także stanowiły świadectwo miłości ojca do syna. Niewątpliwie hetman pokładał w nim duże nadzieje na kontynuowanie tradycji rodowej. Widział w Janie zaradnego gospodarza, odpowiedzialnego ojca oraz męża, obywatela oddanego krajowi i wiernie mu służącego. Wszelkie majątki miały mu przypaść $\mathrm{w}$ udziale dopiero $\mathrm{w}$ chwili ożenku, czego dopilnować powinna matka. Dopiero wówczas możliwe byłoby odziedziczenie „Rubieszawa, Kałuszy, ukrainnych majętności, a i Dziedziłłowa z Kulikowem"36. Pewną część posiadanych dóbr wdowa zapewne sprzedała już wcześniej, aby wykupić syna $\mathrm{z}$ niewoli tureckiej oraz głowę męża. Regina miała zebrać na ten cel trzy miliony złotych polskich, zaś sam król wyraził zgodę na bicie własnej monety w Żółkwi ${ }^{37}$.

${ }^{34}$ Jakub Sobieski dziękuje na pogrzebie J.M.P. Stanisława Żółkiewskiego Kancl<erza> i Hetmana Wielk<iego> Koronnego, w: Mówca polski..., s. 4.

${ }^{35}$ G. Mroczek, Wychowanie syna w świetle testamentów Stanisława Żółkiewskiego, „Rocznik Przemyski” 53 (2017), z. 3: Historia, s. 19-34.

36 Testament B, s. 292

37 S. Barącz, Pamiątki miasta Żółkwi, Lwów 1852, s. 21. 
Niewątpliwie Stanisław starał się przygotować syna do pełnienia ważnych urzędów w państwie oraz nauczyć rzemiosła wojskowego, dlatego zabierał go na wyprawy wojenne. Tak też się stało w 1620 roku. Dla Jana kampania cecorska nie zakończyła się tak tragicznie jak dla jego ojca: został "tylko" wzięty do niewoli ${ }^{38}$ i trafił do chana krymskiego Dżanibega Gereja, „od którego w następnym roku został uwolniony" ${ }^{39}$. W 1623 roku brał udział w sejmie warszawskim. Gdy przebywał w stolicy, odnowiła się jego rana z bitwy cecorskiej, dostał silnej gorączki i zmarł. Podczas pogrzebu mowę ponownie wygłaszał Jakub Sobieski ${ }^{40}$. Nawiązał w niej do antycznej tradycji umieszczania na budowlach znamiennej sentencji non plus ultra. W kontekście kolejnego, przedwczesnego pogrzebu mówca wyrażał nadzieję na ustanie trosk i smutków, które doświadczały dom Żółkiewskich: „wytchnienia jednak w żalach i osuszenia łez już by mógł być kres naznaczony" ${ }^{\prime 1}$. Autor przywołał motyw zmiennego szczęścia i losu, który nie liczy się z planami ludzkimi, oraz egalitaryzmu śmierci, niezwracającej uwagi na pochodzenie człowieka, jego pozycję w społeczeństwie, i zrównującej wszystkich przed swoim obliczem. Wskazał również na zmienność świata, przywołując przykłady upadających państw, prowincji i miast, na których gruzach wyrastają nowe. Zbyt krótkie życie starosty hrubieszowskiego nazywa ,igrzyskiem losu”"2: na nic się zdało doskonałe pochodzenie, wykształcenie, posiadanie wielu przymiotów ducha i umysłu, które zapowiadały znakomitą karierę „na wielką ozdobę Ojczyzny"43. Sobieski wspomniał dobre wychowanie Jana, o które szczególnie zabiegał jego ojciec, ucząc go rzemiosła wojskowego podczas wspólnych wypraw i wpajając odpowiedzialność za kraj. Jego ocalenie z pogromu po bitwie cecorskiej i powrót do Rzeczypospoli-

\footnotetext{
38 A.S. Radziwiłł, Rys panowania..., s. 69.

39 Ibidem, s. 71.

${ }^{40}$ Tenże dziękuje na pogrzebie żałosnym Jana Żółkiewskiego staro<sty> hrub<ieszowskiego>, w: Mówca polski..., s. 7-10.

${ }^{41}$ Ibidem..., s. 7.

42 Ibidem, s. 8.

43 Ibidem.
} 
tej z niewoli tureckiej odczytywano jako szczęśliwą odmianę fortuny i zwiastun życia „sławy i nieśmiertelnych ojcowskich dzieł dziedzica”44. Jednakże inne były plany Boga, skoro „dopuścił nieużytej śmierci kosą swoją podciąć tak ślicznie kwitnący Kłos” ${ }^{35}$. Ojczyzna straciła zatem kolejnego potrzebnego obywatela, władca oddanego sługę, a najbliższa rodzina męża, ojca i brata. Sobieski przypomniał również swoją poprzednią mowę z pogrzebu hetmana i kanclerza wielkiego koronnego, w której życzył szybkiego powrotu do kraju syna, będącego wówczas w niewoli tureckiej. Los ponownie okazał się jednak przewrotny: zgromadzeni w Żółkwi odprowadzali na wieczny odpoczynek zaledwie trzydziestodwuletniego mężczyznę. Wraz z ciałem Jana chowano głowę jego ojca, „wielkie i kosztowne skarby Ojczyzny”46. Na zakończenie mówca w imieniu wdowy i matki podziękował obecnym za przybycie oraz prosił Boga o „oddalenie podobnych żalów” ${ }^{47}$ od wszystkich uczestników pogrzebu.

16 grudnia 1624 roku $^{48}$ w kolegiacie żółkiewskiej odbył się kolejny pochówek. Tym razem odprowadzano na wieczny odpoczynek Reginę. O małżonce hetmana Żółkiewskiego nie wiemy zbyt wiele. Pochodziła ze znanego w ziemi przemyskiej rodu Herburtów, była córką Jakuba, dziedzica położonej na tych terenach wsi Miżyniec. Para pobrała się w 1589 roku w katedrze lwowskiej. Małżonków dzieliło 19 lat różnicy i pochodzenie, gdyż ojciec Reginy, posiadając tylko Miżyniec, nie zaliczał się do bogatej szlachty. Najwięcej informacji o usposobieniu Reginy, jej życiu i wpływie na męża możemy czerpać z jej korespondencji nie tylko ze Stanisławem, ale też z Zamoyskimi

44 Ibidem.

45 Ibidem, s. 9.

46 Ibidem.

47 Ibidem, s. 10.

${ }^{48}$ Mimo pojawiającej się w literaturze innej daty pogrzebu Reginy Żółkiewskiej (16 grudnia 1625), zdecydowałam się na jej weryfikację i zmianę. Po analizie mowy Jakuba Sobieskiego oraz kazania Wojciecha Ghizy, posługującego wówczas w Żółkwi franciszkanina, przesunęłam datę pogrzebu na grudzień 1624 roku (wg W. Ghizy pogrzeb odbył się 17 grudnia). 
oraz Zebrzydowskimi, z którymi łączyły ją więzy pokrewieństwa ${ }^{49}$. Słynęła $z$ wielkiej pobożności, zaradności, dbała o rozwój majątku, zwłaszcza miasteczka Żółkiew, założonego w 1597 roku, a przede wszystkim była kochającą żoną i matką Zofii (ur. 1590), Jana (ur. 1591) oraz Katarzyny (ur. 1594) ${ }^{50}$. Uczucia obojga małżonków są doskonale widoczne $\mathrm{w}$ ich listach oraz testamentach. W pierwszym testamencie, z 1606 roku, hetman wspominał: „W jakiej zgodzie i w jakiej miłości żyliśmy z sobą" ${ }^{51}$. Ze względu na liczne obowiązki publiczne Stanisława to Regina w dużej mierze przejęła pieczę nad sprawami gospodarskimi, o czym hetman również pisał $\mathrm{w}$ akcie swojej ostatniej woli: „Domowe insze rzeczy, o sprzętach, o dochodach, tobie lepiej niźli mnie są wiadome, bom swe myśli w sprawach Rzeczypospolitej utopił, swoich zaniedbawszy"52. Nie ulega wątpliwości, że nie był to łatwy związek. Regina często pozostawała sama, w swoim testamencie napisała o licznych problemach podczas nieobecności męża, „kiedy na miejsca wojenne i niebezpieczne częstokroć odjeżdżał i po dwie lecie bez małego czasum go nie widziała"53. Zapewne ostatni list od męża, pisany w tonie rezygnacji i poddania się wyrokom losu, musiał wprawić małżonkę w ogromny niepokój, skoro postanowiła opuścić Żółkiew i wywożąc ze sobą kosztowności, udać się do Zamościa ${ }^{54}$. Swój przyjazd poprzedziła dramatycznym listem, w którym błagała Tomasza Zamoyskiego II (1594-1638) o zebranie wojska i ruszenie hetmanowi koronnemu na ratunek ${ }^{55}$.

${ }^{49}$ Matką kanclerza i hetmana wielkiego koronnego była Anna Herburtówna, zaś małżonką wojewody krakowskiego Mikołaja Zebrzydowskiego Dorota, siostra Reginy, zob.: K. Niesiecki, Herbarz polski, wyd. J. Bobrowicz, t. 4, Lipsk 1839, s. 351.

50 J. Besala, Stanisław Żółkiewski, s. 120.

51 Testament A, w: Pisma..., s. 171.

52 Ibidem, s. 179.

53 Testament Reginy z Fulsztyna Herburcianki Żółkiewskiej kopiowany z oryginału własna jej ręką spisanego 1610, dnia maja 13, „Biblioteka Warszawska. Pismo poświęcone naukom, sztukom i przemysłowi” 2 (1845), s. 448.

54 S. Żurkowski, Żywot Tomasza Zamojskiego..., s. 44.

${ }_{55}$ R. Żółkiewska do T. Zamoyskiego z Żółkwi (bez daty dziennej) 1620, w: Listy Stanisława Żółkiewskiego 1584-1620, wyd. J.T. Lubomirski, Kraków 1868, s. 147. 
Podczas pogrzebu Reginy ponownie przemawiał Jakub Sobieski ${ }^{56}$. Podobnie jak w poprzednich mowach chętnie stosował liczne metafory oraz odwołania do kultury antycznej. Orację rozpoczynała refleksja nad kondycją człowieka i jego zmiennymi losami, na które nie ma on wpływu. Sobieski nazywał dom Żółkiewskich „zacnym a smętnym"57, ze względu na liczne tragedie, które go dotknęły, bowiem w ciągu trzech lat pochowano troje członków tego rodu. Autor przypomniał swoim słuchaczom „rozum i wspaniałe serce" ${ }^{58}$, jakim wyróżniała się małżonka hetmana, a które uczestnicy pogrzebu „dobrze znali” ${ }^{59}$. Sobieski przypomniał, że zmarła pochodziła ze znanego i zasłużonego dla Rzeczypospolitej rodu oddanych senatorów, którzy „wyniosłymi godnościami, rozumami w tej Rzeczypospolitej kwitnęli” ${ }^{60}$. Wspomniał również znane greckie oraz rzymskie niewiasty, których cnoty sławili poeci, stwierdził jednocześnie, że Regina niczym im nie ustępowała i może być dla współczesnych i potomnych przykładem hartu ducha, a także silnego charakteru w obliczu ciężkiej próby, jaką były utrata męża oraz wzięcie do niewoli jedynego syna. Zdaniem Sobieskiego Regina była doskonałą towarzyszką życia Stanisława i matką Jana, w którym orator widział przyszłego następcę ojca na hetmaństwie. Mowę kończyły podziękowania dla niektórych gości: między innymi dla wojewody ruskiego Tomasza Zamoyskiego i jego małżonki Katarzyny Ostrogskiej, wreszcie dla księżny Anny Ostrogskiej, z którą zmarłą łączyła przyjaźń ${ }^{61}$.

${ }^{56}$ Tenże na pogrzebie JMP Pani Reginy Herburtówny Żółkiewskiej Kancl<erzyny> i Hetm<anowej> Koron<nej>, w: Mówca polski..., s. 10-12.

57 Ibidem, s. 10.

58 Ibidem, s. 11.

59 Ibidem.

60 Ibidem.

${ }^{61}$ Ibidem, s. 12. 


\section{Zasady edycji}

Prezentowana edycja została przygotowana zgodnie z instrukcją wydawniczą dla źródeł historycznych autorstwa Kazimierza Lepszego ${ }^{62}$. Posiłkowałam się również wskazówkami zawartymi w zasadach wydawniczych opracowanych przez Jerzego Woronczaka w 1955 roku $^{63}$. Starałam się rozbudować przypisy rzeczowe - zgodnie z zaleceniami Janusza S. Gruchały ${ }^{64}$. Biorąc jednak pod uwagę to, że wymienione zasady nie do końca odpowiadają współczesnym wymogom krytycznego edytorstwa, starałam się wprowadzić zmiany, które z jednej strony zachowałyby styl i wymowę dawnej polszczyzny, a z drugiej uczyniły tekst jasnym i zrozumiałym dla każdego czytelnika, w tym niebędącego specjalistą w dziedzinie historii czy historii języka polskiego. Jeśli chodzi o rozstrzygnięcia szczegółowe:

- zdecydowałam się na pozostawienie skrótów tytulaturowych w formie wersalikowych zbitek na przykład: „WM”/ „Wm” - „Wasza Miłość ”, „JP”, „JMP” - „Jegomość Pan”/,Jegomość Pani”, „WM MMP” - „Waszmoście Moi Mości Panowie”, „MP” - Mości Pan”, „JKM” - „Jego Królewska Mość”, „PNM” - „Pan Nasz Miłościwy”, „PN” - „Pan Nasz”, „Jej KM” - „Jej Królewska Mość”;

- zastosowałam nawias kątowy „<>” do oznaczania rozwinięć lub uzupełnień brakujących liter;

- przyjęłam zasadę pełnego tłumaczenia w nawiasach kwadratowych „[]” zwrotów łacińskich, zapisanych w edycji kursywą;

- uwspółcześniłam interpunkcję oraz poprawiłam błędy językowe z punktu widzenia współczesnej polszczyzny, które ówcześnie błędami nie były (np. zamiast „prętko” - „prędko”);

${ }^{62}$ K. Lepszy, Instrukcja wydawnicza dla źródeł historycznych od XVI w. do poł. XIX w., Warszawa 1953.

${ }^{63}$ Zasady wydawania tekstów staropolskich. Projekt, przykłady oprac. J. Woronczak, [red. nauk. M.R. Mayenowa przy współudz. Z. Florczak], Wrocław 1955.

${ }^{64}$ J.S. Gruchała, Głos w sprawie komentarza, w: Edytorstwo źródeł. Różne drogiwspólny cel, red. A. Perłakowski, Kraków 2017, s. 11-33. 
- zdecydowałam się jednak na zachowanie oryginalnego brzmienia nazw własnych i geograficznych;

- zachowałam zapis głosek ,i”, „,", „y” w słowach obcego pochodzenia (np. „ekspedycyje”, „sentencyje”, „transakcyje”, konfidencyje”, „okazyje” etc.);

- zachowałam dawne przyrostki czasowników (np. „zostawuje”), pozostawiłam także dawne użycia niektórych form czasownikowych (np. „możem”, musiemy”) oraz wariantywne postaci zaimka (np. „wszytcy”) czy spójnika (np. „abo”);

- zdecydowałam się pozostawić archaiczne formy morfologiczne (np. „wszytko”, „doma”, „kożdy”, „upatrował”, „unkniono”);

- zachowałam wydłużoną artykulację spółgłosek (np. „affekt”, „kolledze”, kassowano”, „supplikę”);

- zlikwidowałam oboczności spółgłosek dźwięcznych i bezdźwięcznych (np. „bespieczeństwo” - „bezpieczeństwo”, „bydź” - „być”). 


\section{Tekst źródłowy}

\section{Mówca polski, albo wielkich senatorów powaga i ojczystą wymowa oratorów sejmowe i pogrzebne mowy do głośnej wieków potomnych pamięci podane, tom pierwszy. Druga edycyja, auctior [ed. Jan Pisarski] w roku Pańskim 1683. W Kaliszu, w Kole $<$ g $>$ ium Societatis Iesu.}

\section{[s. 1]}

Jakub Sobieski dziękuje na pogrzebie JMP Stanisława Żółkiewskiego, Kancl<erza> i Hetmana Wielk<iego > Koronnego

Gdyby to podobna Rzeczpospolitą Ojczyznę naszę miłą ze wszytkich szerokich ich granic oraz zgromadziwszy, na dzisiejszy żałosny akt zaprosić, ona by żałosnej ceremonijej, pierwszą i ostatnią pompą, a dzielnego Hetmana swego murami samemi słusznie być miała, aby zbroczone krwią kości jego na ramiona swe wziąwszy, wszytkiemu światu jako sławy, cnoty i męstwa widok wystawiwszy, nie prochem je przykryła, ale owszem w sercach i umysłach nas wszytkich wspaniały im grób zbudowawszy, miasto ziemie w wiecznej potomnych czasów pamięci tak zacny klejnot pochowała. Zdał-ci by się wprawdzie umarłego nowy jakiś obchód, ale też i żywego niezwyczajne były cnoty, a wielkie dzieła wielkie za sobą pociągają przykłady i wysokie cnoty czcią nieba sięgają. Już by nam nie trzeba po greckich ani rzymskich dziejach jako oni swoich bo<h>atyrów mauzolea za ołtarze i kościoły mieli? Jako hetmanom swoim publico luctu [z publiczną żałobą] rocznice czynili, gdy ich chwalili często, więc nie tylko wszytkie stany i urzędy wszelkie, ale wojska, narody, państwa, ludzie i królestwa za jedną się truną cisnęli. Nic ja nie wątpię, że lubośmy tu wszyscy przybyć nie mogli, ponieważ on dla wszytkich zdrowie położył i ci, co doma pozostali, i cośmy się tu stawili, jednostajnym głosem 


\section{[s. 2]}

mówić możem, że Hectora flemus [Hektora opłakujemy]. Jeżeli takich płakać przystoi, a nie raczej im świętą, że tak rzekę, zazdrością zazdrościć i w niebie chwały, i tu na ziemi, póki świat stać będzie, nieśmiertelnej sławy. Tych pospolicie żałować dobrze, którzy umierając, samych siebie żałują abo przez wszytek wiek swój w pieszczocie i w gnuśności wychowani umierają; tych płakać, którzy z tego świata schodzą, nic na nim nie uczyniwszy, ani do przysługi, ani do sławy. Ale którzy dla Ojczyzny prace, trudy, niebezpieczeństwa, koszty i bezsenne nocy za jednę sobie rozkosz poczytali, którzy na ciele rany za kosztowne męstwa swego upominki oddawali, częstemi przewagami jako wabiem jakim śmierć samę wabili, nic w sercu, nic w ustach, jedno sławną śmierć nie miewali i takąż z świata zeszli, tym i za żywota wielce się dziwować i po śmierci nie tak łzami opłakiwać, jako encomiis [pochwałami] czcić i wynosić przynależy. Mówmy-ż tedy już bezpiecznie, satis Hector habet [dosyć ma Hektor], dosyć na tym, że Ojczyzna, cives [obywatele] i wszyscy dobrzy żałują tego, że ten tak wielki człowiek umarł, dosyć i w tym, że kroniki dziełami, wiek laty, dom swój ozdobami i przedniejszymi w tym państwie tytułami napełniwszy, na tak sławnym wielkich onych bohaterów i hetmanów łożu, za wiarę świętą i Ojczyznę poległ. Mało na tym długo i szczęśliwie żyć, ale cnotą i niepośledniemi zabawami czasy swoje mierzyć, to najprzedniejsze szczęście. Nader tedy szczęśliwy ten zacny Kanclerz i Hetman Koronny, że nie miesiącami ani laty, jako to bywa, liczył dni wieku swego, ale prawie sudore et sanguine [potem i krwią], insza coraz wszytko robota, coraz nowa praca, różnemi to doma Ojczyzny usługami, to za ścianą Rzeczypospolitej ekspedycyjami. Wiódł jakiś spór młodszy wiek jego z podeszłym, że pojźrzawszy na czerstwość, ochotę i trudy je[s. 3]

go, zdał się być w starości młodym; a kiedy kożdy więc pospolicie spracowaną już głowę do domowych kątów na wczas i odpoczynek skłania, to on w te czasy najbardziej ją schorowawszy in hosticum [do kraju nieprzyjacielskiego] wyniósł i tam za nas wszytkich sławnie ją położył. Owo zgoła przez żywot jego jednakim to jest, wielkim człowiekiem zawsze widziała go Ojczyzna i jej się urodziwszy, 
jej idąc torem zacnych przodków swych, oddał i miłość swoję. Nieco w cudzej ziemi na ćwiczeniu i naukach przepędziwszy, udał się na dwór ś<więtej> pamięci Króla Stefana ${ }^{65}$. Jeżeli rośnie stąd nie lada jaka chwała principibus placuisse viris [podobać się władcom], toć on wielce stąd sławny, że oraz wielkiego dwiema rozumu i animuszu ludziom do smaku przypadł, tak roztropnemu Królowi i tak biegłemu słudze i urzędnikowi jego, sławnej pamięci Jego MP Zamoyskie$\mathrm{mu}^{66}$. Przyjął go na dwór swój Król Stefan za sekretarza, w moskiewskich ekspedycjach zażywał go do różnych posług ${ }^{67}$ i co w panach rzadko, przypuszczał go ad penetralia aulae et imperii arcana [do wnętrza dworu i do tajemnic rządów]. Nastał szczęśliwie panujący KIMPN Mwy ${ }^{68}$, tego jako pana nowego ochotnie przywitać usiłował, że nie mógł mu przy oddaniu posłuszeństwa większej dani i droższego upominku ofiarować nad krew swoję własną, którą za dostojeństwo jego w potrzebie byczyńskiej ${ }^{69}$ hojnie rozlał. Zaczym nastąpiły

65 Stefan Batory (1533-1586) - król Polski i wielki książę litewski w latach 1576-1586. Znakomity dowódca, wyprawił się przeciwko Moskwie (1577-1582). Stanisław Żółkiewski był jego sekretarzem. Warto nadmienić, że 12 maja 1584 roku Żółkiewski pojmał słynnego banitę Samuela Zborowskiego (ok. 1540-1584).

${ }^{66}$ Jan Zamoyski (1542-1605) - podkanclerzy koronny w latach 1576-1578, kanclerz wielki koronny w latach 1578-1605 i hetman wielki koronny w latach 1581-1605. Jeden z najbliższych współpracowników króla Stefana Batorego. Humanista i znany orator, założyciel Akademii Zamoyskiej (1595), twórca Ordynacji Zamoyskiej (1589).

${ }^{67}$ Nawiązanie do wojny Stefana Batorego z Moskwą, w której brał udział również Żółkiewski, wówczas pod komendą Jana Zamoyskiego. Odznaczył się w bitwie pod Zawołoczem (5-23 października 1580 r.) i podczas oblężenia Pskowa w 1581 roku.

${ }^{68}$ Król Jego Mość Pan Nasz Miłościwy. Zygmunt III Waza (1566-1632) - król Polski i wielki książę litewski w latach 1587-1632 oraz król szwedzki w latach 15921599. Syn króla szwedzkiego Jana III Wazy i królewny polskiej Katarzyny Jagiellonki, po kądzieli wnuk króla Zygmunta Starego i królowej Bony. Prowadził liczne wojny, między innymi ze Szwecją, z Moskwą, Portą Otomańską.

${ }^{69}$ Bitwa pod Byczyną - starcie wojsk polsko-litewskich, dowodzonych przez hetmana Jana Zamoyskiego, z oddziałami austriackimi arcyksięcia Maksymiliana Habsburga z 24 stycznia 1588 roku, zakończone zwycięstwem hetmana i wzięciem do niewoli arcyksięcia oraz jego zwolenników. Arcyksiążę został zatrzyma- 
zasługi, a za zasługami wysługi honorum et dignitatum [zaszczytów i godności]. Dana mu polna buława ${ }^{70}$, aby sławnej pamięci nieboszczykowi panu Zamoyskiemu hetmanowi wielkiemu wojennych prac dopomagał. Azaż nie dopomagał? Świadkiem są cecorska ${ }^{71}$, multań$\mathrm{ska}^{72}$, inflancka ${ }^{73}$ ekspedycja. Aleć i z regimentu jegoż samego, jako zwycięstwa, łupy i triumfy odnosiła Ojczyzna, żadnemu nie tajno. Niemała to przysługa była, zniesione kozackie tabory i do działa przy[s. 4]

kowany on niezbożnego Ojczyzny własnej swej łupu i nie mniej szlachty zacnej krwi, nienasycony Nalewajko ${ }^{74}$. Wielka Ojczyźnie

ny w Krasnymstawie jako więzień Jana Zamoyskiego. Na wiosnę 1589 roku sejm pacyfikacyjny ogłosił amnestię, uwalniając Maksymiliana i jego zwolenników. Formalnym zakończeniem konfliktu było podpisanie traktatu bytomsko-będzińskiego 9 marca 1589 roku.

${ }^{70}$ Stanisław Żółkiewski był hetmanem polnym koronnym w latach 1588-1618.

71 Pierwsza bitwa pod Cecorą, którą stoczono w dniach 19-20 października 1595 roku podczas wyprawy Jana Zamoyskiego do Mołdawii. Wyprawa związana była z koncepcją stworzenia pomiędzy Rzecząpospolitą a Portą Otomańską tak zwanych państw buforowych, które chroniłyby ziemie koronne przed najazdami tureckimi.

${ }^{72}$ Jan Zamoyski wyprawił się do Mołdawii na Wołoszczyznę przeciwko Michałowi Walecznemu w 1600 roku. Przyczyną było obalenie hospodara mołdawskiego Jeremiego Mohyły oraz jego brata, hospodara wołoskiego Szymona Mohyły, przychylnych Rzeczypospolitej. Kluczowym momentem konfliktu była bitwa pod Bukowem stoczona 20 października 1600 roku, zakończona zwycięstwem wojsk Zamoyskiego.

${ }^{73}$ Wyprawa do Estonii odbyła się w 1602 roku podczas wojny polsko-szwedzkiej o Inflanty w latach 1600-1611. Żółkiewski prowadził tam wojnę zaczepną, w czerwcu 1602 roku pobił Szwedów w bitwie pod Rewlem. W trakcie tej kampanii wyróżnił się zdobyciem Wolmaru i przyczynił się do kapitulacji Szwedów w Białym Kamieniu.

${ }^{74}$ Semen Nalewajko (zm. 1597) - właściwie Semerij Nalewajko, przywódca powstania kozackiego w latach 1595-1596. Wśród przyczyn rewolty były między innymi prywatne animozje między Nalewajką a Marcinem Kalinowskim. Dowództwo nad wojskami koronnymi, które miały stłumić powstanie, zostało Żółkiewskiemu powierzone w lutym 1596 roku. Hetman przystał na to niechętnie, ponieważ chorował, a ponadto nie zgadzał się z polityką wyzyskiwania ludności poddanej przez szlachtę. Dążył do pokojowego rozwiązania tej sytuacji - „wolę chore członki leczyć niż obcinać”. Jednak nie obyło się bez rozlewu krwi: 3 kwietnia 1596 roku hetman pokonał oddziały powstańców koło uroczyska Ostry Kamień. W dniach 26 maja7 czerwca trwało oblężenie obozu kozackiego w okolicach Łubnia nad rzeką Sołoni- 
pociecha tatarskie na Dzikich Polach ${ }^{75}$ liczyć mogiły. Kiedy zaś północne niemal wszytkie kraje na imię Króla JM Władysława ${ }^{76}$ czołem mu uderzyły, kiedy bitnego narodu trojem murem i trzema rzekoma obtoczona stolica ${ }^{77}$, skarby swe od dawnych zbiorów nieco już spleśniałe otworzywszy, jemu się pokłoniła, kiedy car moskiewski ${ }^{78}$, szósty na świecie monarcha, $\mathrm{z}$ plemieniem swym wydany przezen in theatro [w teatrze] Rzeczypo<spolitej> w łykach Królowi JM oddany ${ }^{79}$, jakie to były dzieła, już i cudzoziemskich narodów postronne pióra,

cą. Liczne choroby, brak wody, pożywienia i paszy dla zwierząt wymusiły kapitulację Kozaków. Przy rozwiązywaniu taboru doszło do rzezi na ludności kozackiej, co położyło się cieniem na dalszych relacjach polsko-kozackich i nie przyniosło sławy samemu hetmanowi.

${ }^{75}$ Dzikie Pola - umowna nazwa krainy geograficznej położonej w województwie kijowskim, na wschód od Dniestru, na południe od Kudaku i porohów dnieprowych. Dzikie Pola ciągnęły się na wschód aż do Donu, a na południe do wybrzeży Morza Czarnego.

${ }^{76}$ Władysław IV Waza (1595-1648) - król Polski i wielki książę litewski w latach 1632-1648, tytularny król Szwecji w latach 1632-1648, formalnie car moskiewski w latach 1610-1613, a tytularny do roku 1634. Jedyny syn Zygmunta III Wazy i jego pierwszej żony Anny Habsburżanki. W oracji Sobieski przypomina wojnę z Moskwą (od 1609) i starania Władysława o koronę carską. Na początku 1610 roku bojarzy, niezadowoleni z rządów cara Wasyla Szujskiego, ofiarowali tron Władysławowi. Stanisław Żółkiewski prowadził z bojarami rokowania w tej sprawie.

77 Moskwa.

${ }^{78}$ Wasyl IV Szujski (1552-1612) - car moskiewski w latach 1606-1610, ostatni władca z dynastii Rurykowiczów. Został zdetronizowany po zwycięstwie Żółkiewskiego pod Kłuszynem (4 lipca 1610) w wyniku buntu bojarów. Po zajęciu Moskwy przez hetmana trafił do polskiej niewoli. W sierpniu 1611 roku wywieziono go do Warszawy. Po triumfie wojskowym hetmana (29 października 1611) Wasyl Szujski jako więzień króla polskiego przebywał najpierw w pałacu na Mokotowie, później w zamku w Gostyninie. Pozostawał pod strażą, ale miał możliwość kontaktowania się ze światem zewnętrznym i przyjmowania gości. Zmarł w czerwcu 1612 roku. Podejrzewano otrucie, ale prawdopodobnie przyczyną śmierci była zaraza.

${ }^{79}$ Nawiązanie do hołdu carów Szujskich (braci: Wasyla, Dymitra i Iwana), który złożyli Zygmuntowi III Wazie i królewiczowi Władysławowi podczas sejmu warszawskiego w 1611 roku. Uroczystości odbyły się 29 października. Hetman Żółkiewski triumfalnie wjechał przez Krakowskie Przedmieście do Zamku Królewskiego, wiodąc ze sobą więźniów. Ci w obecności szlachty i senatu złożyli królowi 
od nienawiści i pochlebstwa próżne, pisać i u nas samych nie przeżyta następujących wieków pamięć w nieśmiertelnej sławie, jako w twardym jakim kamieniu ryć, tak zacne triumfy nie przestanie. W zawierusze zaś przeszłej domowej ${ }^{80}$, gdzie o konfidencyją najtrudniej, że Króla JM zdrowie i panowanie prawie na ręku piastował i koronę już mu z głowy nachyloną utwierdził, że i w radach, i sentencyjach swoich przez te czasy nic inszego nie upatrował, jedno ono parce civibus [oszczędzaj obywateli], ma mu być za co pan z Ojczyzną powinien. Jakoż oświadczył mu JKM potym łaskę swoję z kasztelaństwem lwowskim, a potym pomknąwszy go na wyższy stołek województwa kijowskiego, a potym zemknąwszy sędziwą a zrobioną głowę jego, wprawdzie ad summam dignitatem [do najwyższej godności], ale do wielkiej pracy, gdy mu z buławą wielką pieczęć wielką koronną konferować raczył ${ }^{81}$. Zbraniał się on długo, nim ten urząd przyjął, różnych przyjaciół rady zasiągając, sam się z sobą biedził, aż potym idąc za wolą Bożą, u którego w ręku serca są pomazańców i namiestników Jego na ziemi, wziął się za urząd ten, w którym jako się sprawował,

Zygmuntowi III Wazie przysięgę wierności. Towarzyszyli im również Michał Szein, dowódca twierdzy smoleńskiej, i patriarcha moskiewski Filaret.

${ }^{80}$ Rokosz sandomierski (inaczej rokosz Zebrzydowskiego) - bunt szlachty przeciwko Zygmuntowi III Wazie w latach 1606-1607. Wśród przyczyn wyróżnić można: absolutystyczne dążenia władcy, jego sprzyjanie jezuitom i cudzoziemcom, plany ograniczenia władzy sejmu na rzecz króla itd. Wśród przywódców buntu byli między innymi wojewoda krakowski i marszałek wielki koronny Mikołaj Zebrzydowski (1553-1620), podczaszy litewski Janusz Radziwiłł (1579-1620), starosta zygwulski Stanisław Stadnicki (ok. 1551-1610) i starosta dobromilski Jan Szczęsny Herburt (1567-1616). 24 czerwca 1607 roku pod Jeziorną buntownicy ogłosili detronizację Zygmunta III. Losy rokoszu rozstrzygnęła bitwa pod Guzowem, stoczona 5 lipca tego samego roku. Wojska królewskie, dowodzone między innymi przez hetmana polnego Stanisława Żółkiewskiego, rozgromiły oddziały rokoszan. Formalnie uspokojenie sytuacji i przeprosiny króla przez rokoszan nastąpiły dopiero podczas sejmu pacyfikacyjnego w 1609 roku.

${ }^{81}$ Stanisław Żółkiewski otrzymał urząd kasztelana lwowskiego 30 kwietnia 1590 roku, urząd wojewody kijowskiego 28 marca 1608 roku, urząd hetmana wielkiego koronnego 6 lutego 1618 roku, a urząd kanclerza wielkiego koronnego 6 marca 1618 roku. 


\section{[s. 5]}

w świeżej wszyscy macie WM pamięci. A kto się naliczy różnych jego ukrainnych co rok ekspedycji, to z Kozaki, to z pohańcy transakcyji? $\mathrm{W}$ tej ostatniej imprezie swej, jako się nie tylko dzielnym hetmanem, ale i nieustraszonym mężem, nieprzerwanym w głodzie, w niespaniu, w pracy żołnierzem być pokazał, tych wszytkich języki jednostajnie świadczą, którychkolwiek stamtąd dusze wychodzą. Odpowiedział cygnea voce [łabędzim głosem] w liście swym do Jego KM następujące niebezpieczeństwa, pożegnał Ojczyznę i pana i z tym się animuszem do Wołoch puścił, aby był jako fata [losy] chciały, trupem swym drogę do ostatniej Ojczyzny zguby pohańcom zawalił. Żal się Boże, że tamte brzegi dniestrowe i góry już Ojczyzny, które na koniec jego bez wszelakich affektów patrzały, przemówić nie mogą, aby one same już w te czasy nie hetmana, ale wielkiego Męża i Bohatera tak mężne $\mathrm{z}$ tego świata zeście nam opowiedziały. Życzęć znowu Ojczyzno moja, abyś się teraz na ten plac stawiła i przy tym tak zacnym gościom podziękowaniu samaś wprzód Hetmanowi swemu podziękowała, że zdrowie twoje przez tak długi czas w ciężkich razach piastował, za twoje szczęście i bezpieczeństwo wszytkim się niebezpieczeństwom zastawiał; abyś w pokoju kwitnęła, on wojował, abyś wczasów swych zażywała, on się na niewczasy puszczał, abyś na ostatek długo fortunnie żyła, on poległ i tak cię pożegnał Cecidit columen Patriae mole fatorum [Upadła podpora Ojczyzny pod ciężarem losów]; toćby Ojczyźnie przynależało. Tę zaś Jej MP Kanclerzyna ${ }^{82}$,

82 Regina z Herburtów Żółkiewska (1566-1624) - od 1589 roku żona kanclerza i hetmana wielkiego koronnego Stanisława Żółkiewskiego. Była córką Jakuba Herburta i Katarzyny z Wapowskich. W literaturze przedmiotu powszechnie uznaje się ją za wzór żony i matki, dzielnie znoszącej liczne nieobecności męża. W jego zastępstwie czuwała nad rodzinnym majątkiem, szczególnie założoną w 1597 roku Żółkwią. Opiekowała się ubogimi, kościołami i zakonami - poczyniła dla nich liczne zapisy w swoim testamencie. Data śmierci Reginy Żółkiewskiej nie jest w literaturze dokładnie wyjaśniona. Pojawiają się daty 1625, 1626, a nawet 1623 (sic!). Za innymi historykami przyjęłam datę 6 listopada 1624 roku. Por. Genealogia, oprac. W. Dworzaczek, t. 2: Tablice, Warszawa 1959, tablica 147. Daniłowicze h. Sas; K. Nie- 
ta zacna utrapiona matrona powinność swoję być czuje, aby uniżenie naprzód Jego KMP swemu mił.<ościwemu> podziękowała, że pomniąc na krwawe przez wszytkie szczęśliwe JKM panowanie i wierne posługi, jej tę ciemną żałobę i grób wielkiego sługi swego łaską swą [s. 6]

pańską oświecić prawie raczył. A że przez Ww. mój MP wojewodo kijowski w dom żałosny szlachecki sług swych wchodzić nie zbrania się, Pana Boga o to serdecznemi modłami swemi, której więc wagę swą miewać zwykły, prosić nie przestanie, aby na pomyślne $\mathrm{w}$ tak kwitnącym państwie swym, jako i w domu królewskim pociechy długo patrzać raczył. I Jej KM MP starosto sokalskii ${ }^{83}$ uniżenie dzięku-

siecki, Herbarz polski, s. 351; L. Podhorodecki, Wielki hetman Rzeczypospolitej..., s. 42-44. Ciekawym wątkiem, wartym osobnego opracowania, jest Kazanie żałobne na pogrzebie [...] Reginy Żółkiewskiej z Felsztyna kanclerzyny i hetmanowej wielkiej koronnej autorstwa franciszkanina $\mathrm{z}$ Żółkwi. Według strony tytułowej kazanie zostało wygłoszone 17 grudnia 1624 roku w Żółkwi, a wydane po 20 stycznia 1625 roku w Zamościu. Datę wydania tego kazania podaje Wacław Maciejowski (Piśmiennictwo polskie od czasów najdawniejszych aż do roku 1830, t. 3, Warszawa 1852, s. 703) i Encyklopedia powszechna S. Orgelbranda (t. 9, Warszawa 1862, s. 867). Estreicher przepisał te lakoniczne informacje w swojej Bibliografii. Autorzy hasła w Bibliografii polskiej Karola i Stanisława Estreicherów (t. 36, cz. 1, Kraków 2013, s. 110) wskazują, że datę tego wydania należałoby przesunąć na rok 1627 . Wydaje się jednak, że właściwe będzie określenie daty śmierci na rok 1624, zaś pogrzebu na grudzień tego roku, zgodnie ze stroną tytułową kazania Wojciecha Ghizy. Na nagrobku Reginy w kolegiacie w Żółkwi datę śmierci również wpisano błędnie (1626). Napis na nagrobku powstał na podstawie zawierającego literówkę zapisu w Monumenta Sarmatarum Szymona Starowolskiego. Zamiast cyfry „IV” na końcu znalazło się tam „VI”. O pomyłce Starowolskiego wspomina Jerzy Urwanowicz w artykule poświęconym inskrypcjom nagrobnym Żółkiewskich (por. J. Urwanowicz, „Piis manibus”. Inskrypcje nagrobne rodu Żółkiewskich w XVII wieku, w: Cywilizacja prowincji Rzeczypospolitej szlacheckiej. Cykl 2: Nie wszystek umrę. Pamięć o zmarłych w kulturze staropolskiej, red. A. Jankowski, A. Klonder, Bydgoszcz 2015, s. 174).

${ }^{83}$ Tomasz Zamoyski (1594-1638) - starosta sokalski w latach 1631-1638, kanclerz wielki koronny od 1635 roku, wojewoda kijowski od 1619 roku, II ordynat zamojski. Jedyny syn i spadkobierca kanclerza i hetmana wielkiego koronnego Jana Zamoyskiego i Barbary Tarnowskiej. Był dobrze wykształcony, oczytany, znał kilka języków, dobrze orientował się w ustroju Rzeczypospolitej i meandrach staropol- 
je, że JKM nie tylko chrześcijańskiej, ale i pańskiej dobroczynności dopomagać raczy JKM panu naszemu $\mathrm{w}$ tym oświadczeniu przez Ww łaski swej pańskiej; uprzejmie życzy, jako uniżona JKM służebnica, aby wszytkie żale i smutki tak od samej Jej KM jako od świątobliwego potomstwa Jej KM oddalone były. JM ksiądz arcybiskup gnieźnieński ${ }^{84} \mathrm{MP}$ Herburt ${ }^{85}$ niejeden, jako owo mówią, soli korzec zjadszy i w dobrych, i we złych czasach z sławnej pamięci małżonkiem Jej M, jawnie pokazuje, że mu był i za żywota przyjaciel, kiedy i umarlego kościom taką oddaje uczciwość. Za co Jej MP Podkanclerzyna $^{86}$ wielce podziękowawszy, winszuje, aby jako pierwszy i przedniejszy Ojczyzny naszej filar, żył długo na rozmnożenie i podporę tej Rzeczypospolitej naszej. Dziękuję MP podczaszy bełski ${ }^{87}$, że Kanclerzowi, Przyjacielowi i Kolledze swemu i po śmierci takową chęć oświadczać raczy; życzy aby w tych pracach Jego $\mathrm{M}$ pod tak trudne Rzeczypospolitej i Ojczyzny naszej czasy, sam Pan Bóg zdrowiem dobrym i spiritu consilii [duchem rady] posilał. Także i Wm mym MP, którzyście się jedno tu stawili, za tę chrześcijańską i przyjacielską uczynność przeze mnie dziękuje. Aleć MP jeżeli genius [duch] co

skiej dyplomacji. Stanisław Żółkiewski, jego opiekun po śmierci ojca w 1605 roku, wprowadzał go w tajniki życia publicznego.

${ }^{84}$ Wawrzyniec Gembicki (1559-1624) - arcybiskup gnieźnieński i prymas królestwa w latach 1616-1624. Wywodził się ze średniozamożnej rodziny wielkopolskiej. Uczył się w Poznaniu, studiował w Ingolstadt i Krakowie. Pierwsze szlify zdobywał w kancelarii Wojciecha Baranowskiego. Dzięki wsparciu Jana Zamoyskiego został sekretarzem królów Stefana Batorego i Zygmunta III. Był między innymi biskupem chełmińskim (od 1600), kujawskim (1610), podkanclerzym koronnym (1607) i kanclerzem wielkim koronnym (1609). Popierał politykę wschodnią Zygmunta III względem państwa moskiewskiego.

${ }^{85}$ Trudno powiedzieć, o kogo właściwie chodzi. Możliwe, że dotyczy to teścia Stanisława Żółkiewskiego Jakuba Herburta z Felsztyna, być może Jana Leona Herburta (1603-1631) - syna Jana Szczęsnego Herburta (rokoszanina), ostatniego z dobromilskiej linii Herburtów.

${ }^{86}$ Prawdopodobnie błąd Jakuba Sobieskiego. Chodzi w dalszym ciągu o Reginę Żółkiewską, która powinna być określana jako „kanclerzyna”.

${ }^{87}$ Andrzej Lipski (zm. 1622) - podczaszy bełski w latach 1605-1621/1622. 
w ludziach może, jeżeli serce prorok, wieszczy duch w przyrodzonym affekcie bywa, i sam JMP starosta hrubieszyński ${ }^{88}$ więzieniem i ra[s. 7]

zami na placu poczciwości, a posłudze Ojczyzny odniesionymi strapiony, gdzieś tam z turmy swej na niebo poglądając, tylko czuje w sercu swym ten żałosny akt dzisiejszy i nieraz gorzkiemi łzami i z daleka trunę ojca i dobrodzieja swego oblewa, że do tej ostatniej przysługi przybyć według powinności synowskiej nie mógł, z pogańskiej ziemie za tę chrześcijańską uczynność niejednym westchnienie Wm dziękuje. Toż czyniąc i to żałobne wszytko domostwo życzą, aby w pocieszniejszych da Bóg okazyjach tę łaskę Wm odsługować mogli.

\section{Tenże dziękuje na pogrzebie żałosnym Jana Żółkiewskiego,}

Staro $<$ sty $>$ Hrub<ieszowskiego $>$

Chcąc kiedyś antiquitas [starożytność] jakoby zahamować i określić, zbyteczne szczęścia jednego dawnych czasów zwycięzcy, wyryła na dwóch kolumnach one trzy słowa Non plus ultra [Nic ponad to]. I któż by nie życzył, aby przeciwnym sposobem słowa te na bramach gdzie tego zacnego i żałobnego domu na okryślenie żalów i opłakanych nam czasów napisane były, aby smętek po smętku, żałoba po żałobie, a rana po ranie się nie odnawiała, aby kiedy stanął tak żałosnych aktów koniec. Kończąc wprawdzie, żądać tego niepodobna, co się aż z światem kończyć ma, wytchnienia jednak w żalach i osuszenia łez już by mógł być kres naznaczony. Takeśmy wprawdzie sądzili, ale fata [losy] inaczej; inszym z nieba dekretem sentencyją inszą kassowano. Ono dobrze ktoś, lubo jak poganin, wyrzekł Dii nos homines ut pilas habent [bogowie mają nas ludzi za piłki $\left.{ }^{89}\right]$. A cóż inszego ze wszytkim światem od wieków wszytkich

${ }^{88}$ Jan Żółkiewski (zm. 1623) - syn Reginy i Stanisława Żółkiewskich, starosta hrubieszowski w latach 1622-1623.

${ }^{89}$ Jest to niedokładny cytat z prologu Jeńców Plauta (Capt. 22): akt 1, scena VIII, wers 8 . 
się dzieje, podczas berła z motykami, purpury z siermięgami, aza mi, aza się nie mieszają? Na którego kiedy monarchy głowie korona [s. 8]

bez cierni była, o jak wiele razy szczęście stało się nieszczęściem; tu jedna Rzeczpospolita upadnie, ówdzie druga powstaje, jednego państwa koniec, drugiego bywa początek. Prowincyje jedne kwitną, drugie pustoszeją, jednych miast ruiny się walą, drugich ozdobne mury i wyniosłe budynki się świecą, w tych familiach strages [klęska], w owych incrementa [dostatek], w ludziach nawet samych, to w tych ciężki upadek, w onych wysokie szczęście baczymy; gdzie pojrzysz jeno zgoła, wszędzie się rerum humanarum ludibriae [igraszki spraw ludzkich] pokazują. Takowe zaś jakośmy mieli żałosne spectaculum [widowisko] przed oczami zacne to ciało, któreśmy ziemi oddali, sławnej pamięci JMP Starosty Hrubieszowskiego na jakieś prawie, że tak rzekę, igrzysko sobie go były wystawiały fata [losy], zacnym z ojcowskiej i macierzyńskiej liniej ozdobiony klejnotem, potym duszę wysokimi dowcipu i rozsądku darami w wielkie ją cnoty, wspaniałe przymioty przybrawszy, z ćwiczenia i peregrynacyji prowadziły go na wielką ozdobę Ojczyzny, podporę rodziców, pociechę przyjaciół. A co większa, już tu nasyciły się w Ojczyźnie wielkiego ojca oczy, rycerskiemi syna gdziekolwiek się przy nim różnych ekspedycyjach obracał postępkami. W tej ostatniej cecorskiej ekspedycyjej fata [losy] co mu więcej uczynić mogły, jedno, że go z razem tak sławnym, sławy nabawiwszy, żywego $\mathrm{z}$ potrzeby wyniosły. Chciały zaś po tym też fata [losy] trochę się odmienić, podały go przy mężnym $z$ tego świata wielkiej pamięci ojca jego w ręce nieprzyjaciół, tej jednak pociechy pozwoliwszy, że się przecię żyw pozostał sławy i nieśmiertelnych ojcowskich dzieł dziedzic, co wszytko zupełniejszą uciechą powetowały, gdy go z niewoli tamtej do Ojczyzny przywrócieły. Już też bezpiecznie mogliśmy wszytkie zawisne wyroki okrzyknąć Non plus ultra [Nic ponad to]. Czas już [s. 9]

było w tym młodzieńcu domowe calamitates [nieszczęścia] uśmierzyć, dziedziczną sławę wskrzesić i nadzieję Rzeczypospolitej doskonale ucieszyć. Ale ten, który czasy rozdaje, czas swój upatrzył i dopuścił nieużytej śmierci kosą swoją podciąć tak ślicznie kwitnący 
w oczach tej Ojczyzny naszej kłos. Zniknęły wszystkie vota [życzenia] i oczekiwania nasze, umkniono niepoślednej Rzeczypospolitej podpory, obalono przedni w tym domu zacnym filar, tych krajów naszych nie lada jaka okrasa w proch się obróciła. Nabawiła też okrutna śmierć różnie różnych żalu, postradała Ojczyzna potrzebnego civem [obywatela], postradał JKM potrzebnego sługę swego, straciła jedynego i matka syna, i siostra brata, stracili bracia brata tak ukochanego, stracili powinni powinnego, przyjaciele przyjaciela tak miłego. A chcecież jeszcze WM moi MP widzieć, co te fata [losy] więcej umieją? Ciało nieśmiertelnej pamięci JMP Kanclerza i Hetm<ana> Wielk<iego > tejże ziemi, temuż grobowi oddając - o, jakośmy życzyli! - aby był do tej ostatniej posługi syn przytomny. Teraz oraz ciało syna i głowę ojca jego chować nam przychodzi. Godna ta głowa i po śmierci od nas wielkiego poszanowania, która za żywota na tak wielu wojnach, za bezpieczeństwo nasze chętnie się zastawiała i w pokoju przednią radą Ojczyźnie naszej była. Accipimus omen [Przyjmujemy wróżbę], że jako ona, lubo obżałowana od pogan, jest do Ojczyzny swej przyniesiona, tak, da Bóg, głowy przedniejsze nieprzyjaciół Ojczyzny naszej tu swój pogrzeb znajdą. Godzi się tedy jednąż pokryć mogiłą synowskie kości i ojcowską głowę; one rosły na Ojczyzny ozdobę, ta zaś za bezpieczeństwo jej poległa. Wielkieśmy to i kosztowne obadwa skarby w te $<$ n $>$ dół włożyli, które nam niepodobno i spod ziemi na sercach i językach naszych tak wysoko

\section{[s. 10]}

wynieść, jako sobie nieśmiertelna sława gniazdo zasadziła. Żeście tedy Wm Pp do tych smętków Jej MP Podkanclerzyny ${ }^{90}$ i do tak żałosnego aktu przybyli, wielce WMW dziękuje i z zacnym domostwem swym wszytkim Pana Boga prosić zechce, aby tym podobne żale od Wm oddalił, a tę uczynność Wm: w kożdych, a daj Boże pocieszniejszych okazyjach odsługować powinna będzie.

${ }^{90}$ To zapewne błąd Sobieskiego - chodzi o kanclerzynę Reginę Żółkiewską. 
Tenże na pogrzebie JMP Pani Reginy Herburtówny Żółkiewskiej, Kancl $<$ erzyny $>$ i Hetm $<$ anowej $>$ Koron $<n e j>$

Przypatrować się ludzkim przypadkom i przygodom, którym i sam świat, i cokolwiek na nim żyje podlega, jest też to jedno do porządnego na świecie życia barzo potrzebne zwierciadło. Tak bowiem nikt i w największym szczęściu głowy podnieść nie może i ci, którzy do desperacyjej się udają, przy nadziejej zostają, i ci, którzy nadzieją pospolicie żyją, bojaźni nie ujdą. Nuż co dni swe w lamentach i w gorzkości łez swych prowadzą, lepszej i weselszej chwili wyglądać będą, a co wesoły i szczęśliwy wiek wiodą, przydzie się im obawiać, ne extrema gaudii occupet luctus [żeby smutek nie opanował największej radości]. Owo zgoła kontemplacyja takowa, każdy życiu swemu munsztuk i wędzidło przybiera. Leźli gdzie tych czasów większe żałosnych tragedyji i teatrum [teatr] się otworzyło, tedy w tym zacnym a smętnym domu. Trzeci się rok kończy, trzeci się też i pogrzeb odprawuje; żal się do żalu, rana do rany odnawia, a żałoba żałobę z ścian domowych zdziera. Niedawno w ten dół nieśmiertelnej pamięci Wielkiego Kanclerza i Hetmana ciało włożono, a długoż same leżało? Niezadługo potym do niego wniesiono syna, a teraz tamże doprowadzono [s. 11]

i do małżonka żonę, i do syna matkę; że każdy, widząc te żałosne spectaculum [widowisko], i swój, i obcy, i przyjaciel, i nawet nieprzyjaciel, jeśli był jaki, westchnąwszy bezpiecznie rzec może Ecce quam magnifici vastati sunt [Oto jak wielcy zostali spustoszeni]. Tym jednak i pozostałego potomka, i przyjaciół wszytkich ocierają się łzy, że nie w tym niskim grobie wysokich cnót tej matrony pamięć zamyka się. A choćby nic inszego nie było, tylo sam rozum i wspaniałe serce, zdobić ją po śmierci u wszytkich muszą. Którzyście ją jedną WM znali, a wiem, żeście wszyscy, coście się stawić raczyli, dobrze znali, przyznacie, że to wszytko przyrodzoną roztropnością 
swoją wskrzeszała i reprezentowała one wielkie Herburty ${ }^{91}$, stryje $\mathrm{e}^{92}$, dziady $^{93}$ i pradziady ${ }^{94}$ swoje. Którzy razem kiedyś sześcią stołków zasiadając w radzie przy boku pańskim, wyniosłemi godnościami, rozumami i w tej Rzeczypospolitej kwitnęli. Jako zaś w tak ciężkich raziech i wielkich przypadkach, nieustraszone, a nie tylko białogłowskie, ale i męskie, ale rzekę więcej: bohatyrskie serce prawie ukazowała, u wszytkich w podziwieniu to jest i będzie. Najwyższa mądrość, mężnym białogłowom dziwując się jakoś, mówi: Mulierem fortem quis inveniet? Proculet de ultimie finibus pretium eius [Niewiastę dzielną któż znajdzie? Ponad wszelką miarę jej wartośćc5]. $\mathrm{O}$, jako Grekowie siła białychgłów swych mężne animusze wiecznej pamięci piórem swym podali! O, jako Rzymianie to Cleliae ${ }^{96}[\mathrm{Kle}-$ lię], to Corneliae ${ }^{97}$ [Kornelię] dla stałego serca pod niebiosa w dziejach swych wynieśli! Ta zacna (że ją tak nazowę) heroina [bohaterka], słusznie i u tych, i u potomnych wieków wspaniałego umysłu wielom ze czci męskiej znaczny przykład zostawiła. Nic ją po takim szczęściu nagłe nieszczęście nie zatrwożyło, nie przywiodły do żad-

91 Por. przyp. 81.

92 Być może chodzi o Jana Herburta (ok. 1510-ok. 1569/1570) - brata ojca Reginy, podkomorzego przemyskiego w latach 1538-1541, wojskiego przemyskiego w latach 1543-1545, podkomorzego lwowskiego w latach 1545-1558, kasztelana lubaczowskiego w latach 1558-1564 i kasztelana bełskiego w latach 1564-1569.

93 Być może chodzi o Jana Herburta (ok. 1470-1508) - sędziego przemyskiego w latach 1507-1508.

94 Być może chodzi o Jana Herburta (ur. 1460) - posła na sejm radomski w 1505 roku.

${ }^{95}$ Cytat biblijny pochodzi z Wulgaty (Prz 31,10); w przekładzie Biblii Tysiąclecia jest to początek Poematu o dzielnej niewieście: „Niewiastę dzielną któż znajdzie? Jej wartość przewyższa perły”, Pismo Święte Starego i Nowego Testamentu w przekładzie z języków oryginalnych opracował zespół biblistów polskich z inicjatywy benedyktynów tynieckich, red. nauk. A. Jankowski et al., przeł. W. Borowski et al., PoznańOpole 2005, s. 850-851.

96 Klelia - bohaterka jednej z opowieści dotyczącej początków republikańskiego Rzymu, wsławiła się w wojnie z królem Larsem Porsenną, uciekając z niewoli.

${ }^{97}$ Kornelia - matka braci Grakchów, posiadała wszystkie przymioty idealnej rzymskiej matrony. 
nej desperacyjej i niewieściego kwilenia nieznośne domowe żale, gdy oraz i zabitego na posłudze Ojczyzny męża ciało przyniesio[s. 12]

no i od jedynego, a niebezpiecznie samego syna i z ciężkiej pogańskiej niewoli żałosną jako to do matki supplikę oddano, mężnie i skromnie te dotknienia Pańskie znosiła, dobrze wiedząc, że bez woli Jego świętej i włos z głowy spaść nie moż $\mathrm{e}^{98}$. Nie dała żadnego upadłej persony po sobie znaku. Godna zaprawdę tytułu tego, że kiedy była żoną hetmańską. Godna i tego, aby była hetmanów Ojczyźnie swej narodziła, gdyby potomstwu jej Bóg sam wieku przedłużyć chciał. Tąż stałością biedziła się i z chorobami swymi już ostatniemi, niż od nikogo nieprzełomanemu wyrokowi głowę swą skłoniła. I tak przez niemały czas męża swe<go> koroną bywszy, napatrzywszy się tryumfów jego, w pomyślnym szczęściu długo kwitnąwszy, dni swych świątobliwie dokonała. Znać MP chełmski ${ }^{99}$ Jej KM, iż póki żyła, dobrze się jej cnotom i przymiotom przypatrzyła, świadoma będąc i zacnych przodków, i męża jej zasługi, który oto na posłudze KJM na tym sławy i poczciwości łożu poległ. Że tedy przez Wm M łaskę i dobrotliwość pańską i po ześciu jej przy tym żałosnym akcie kościom jej oświadczać raczy, uniżenie JKM JMP wojewoda ruski ${ }^{100}$ i z Jej MP wojewodziną ${ }^{101}$ dziękują. Pana

98 Por. 2 Sm 14, 11; Łk 21, 18; Mt 10, 30.

99 Samuel Koniecpolski (zm. 1641) - kasztelan chełmski w latach 1620-1641.

${ }^{100}$ Jan Daniłowicz (ok. 1570-1628) - wojewoda ruski w latach 1613-1628. Był mężem córki Stanisława i Reginy Żółkiewskich, Zofii. W młodości walczył z Tatarami, razem z Żółkiewskim tłumił powstanie Nalewajki. Hetman polny otaczał go opieką: między innymi polecił go jako swojego podkomendnego Janowi Zamoyskiemu. Daniłowicz uczestniczył w wielu wydarzeniach wspólnie ze swoim opiekunem, stał u jego boku podczas rokoszu Zebrzydowskiego, stawał zbrojnie przeciw konfederacjom żołnierskim, czuwał nad obroną województwa ruskiego po klęsce pod Cecorą w 1620 roku.

101 Zofia z Żółkiewskich Daniłowiczowa (1590-1634) - najstarsza córka hetmana Stanisława Żółkiewskiego i Reginy z Herburtów, od 1605 roku żona podczaszego koronnego, potem wojewody ruskiego Jana, babka Jana III Sobieskiego. Z tego małżeństwa narodziło się czworo dzieci: Zofia Teofila, Stanisław, Jan i Dorota. Po bezpo- 
Boga prosić będą, aby wszytkie żale od domu JKM oddalał. Dziękują MP rozpierski ${ }^{102}$ i księżnej Jej M. Ostrogskiej wojewodzinej wileńskiej ${ }^{103}$, że jako mądra i zacna pani, a stateczna przyjaciółka i po śmierci przyjaźń swą oświadcza, życzą i cale winszują, aby dom księżnej JM wszytkiemi pociechami był napełniony.

tomnej śmierci brata Zofia odziedziczyła wszystkie dobra Żółkiewskich. Jan III wychowywał się pod jej okiem na zamku w Żółkwi. Była fundatorką kościołów i cerkwi oraz poczyniła wiele zapisów, między innymi na rzecz kolegiaty żółkiewskiej. Tam też ufundowała nagrobki zmarłym rodzicom i bratu.

${ }^{102}$ Jan Romiszewski (zm. 1633) - kasztelan rozpierski w latach 1605-1631, podkomorzy koronny w latach $1630-1631$.

${ }^{103}$ Ewidentny błąd wydawcy, gdyż chodzi o wojewodzinę wołyńską, Annę Ostrogską (1575-1635) - żonę Aleksandra Ostrogskiego, wojewody wołyńskiego w latach 1593-1603. 


\section{Bibliografia}

\section{Źródła rękopiśmienne}

Biblioteka Jagiellońska, sygn. 110, List od P. Jazkowskiego do P. podkomorzego bełskiego po ostatnim rozgromieniu taboru wojska naszego w Wołoszech, nie daleko za Dniestrem de data Boryssowa 24 Octrobris 1620.

Biblioteka Naukowa Polskiej Akademii Umiejętności i Polskiej Akademii Nauk w Krakowie, sygn. 1052, Wyprawa cecorska.

\section{Źródła drukowane}

Listy Stanisława Żółkiewskiego 1584-1620, wyd. J.T. Lubomirski, Kraków 1868.

Mówca polski, albo wielkich senatorów powagą i ojczystą wymową oratorów sejmowe i pogrzebne mowy do głośnej wieków potomnych pamięci podane, [ed. J. Pisarski], t. 1, wyd. 2, Kalisz: Kole<g>ium Societatis Iesu, 1683, (egz. Biblioteki Jagiellońskiej, sygn. 19621 I).

Niesiecki K., Herbarz polski, wyd. J. Bobrowicz, t. 4, Lipsk 1839.

Pisma do wieku i spraw Jana Sobieskiego, t. 1, cz. 1, wyd. F. Kluczycki, Kraków 1880.

Pisma Stanisława Żótkiewskiego kanclerza koronnego i hetmana. Z jego popiersiem, wyd. A. Bielowski, Lwów 1861.

Radziwiłł A.S., Rys panowania Zygmunta III, wyd. J. Byliński, W. Kaczorowski, Opole 2011.

Sobieski J., Peregrynacja po Europie (1607-1613). Droga do Baden (1638), wyd. J. Długosz, Wrocław 1991.

Testament Reginy z Fulsztyna Herburcianki Żółkiewskiej kopiowany z oryginału własna jej ręka spisanego 1610, dnia maja 13, „Biblioteka Warszawska. Pismo poświęcone naukom, sztukom i przemysłowi” 2 (1845).

\section{Opracowania}

Barącz S., Pamiątki miasta Żółkwi, Lwów 1852.

Barłowska M., Jakub Sobieski pamięci wielkiego kawalera Bartłomieja Nowodworskiego, Szczecin 2006.

Barłowska M., Na swady sarmackiej placu. O kulturze oratorskiej wieku XVII, Kielce 2001.

Barłowska M., O badaniu staropolskiego oratorstwa (na przykładzie świeckiego oratorstwa epoki baroku), w: Retoryka w Polsce. Teoria i praktyka w ostatnim pótwie$c z u$, red. M. Skwara, Szczecin 2006, s. 75-93.

Barłowska M., Ossoliński, Moskorzowski, Sarbiewski - mowy pogrzebowe. Teksty $w$ dialogu, Katowice 2008. 
Barłowska M., Swada i milczenie. Zbiory oratorskie XVII-XVIII wieku - prolegomena filologiczne, Katowice 2010.

Besala J., Stanisław Żótkiewski, Warszawa 1988.

Bibliografia polska Karola i Stanisława Estreicherów, t. 36, cz. 1, Kraków 2013.

Encyklopedia powszechna S. Orgelbranda, t. 9, Warszawa 1862.

Genealogia, oprac. W. Dworzaczek, t. 2: Tablice, Warszawa 1959.

Gruchała J.S., Głos w sprawie komentarza, w: Edytorstwo źródeł. Różne drogi - wspólny cel, red. A. Perłakowski, Kraków 2017, s. 11-33.

Kicińska U., Wzorzec szlachcianki w polskich drukowanych oracjach pogrzebowych XVII wieku, Warszawa 2013.

Kolbuszewski J., Kryzys, pornografia i renesans śmierci, w: idem, Problemy współczesnej tanatologii, Wrocław 1997, s. 7-16.

Labudda A., Liturgia pogrzebu w Polsce do wydania Rytuału Piotrkowskiego (1631). Studium historyczno-liturgiczne, Warszawa 1983.

Lepszy K., Instrukcja wydawnicza dla źródeł historycznych od XVI w. do poł. XIX w., Warszawa 1953.

Maciejowski W.A., Piśmiennictwo polskie od czasów najdawniejszych aż do roku 1830, t. 3, Warszawa 1852.

Maciszewski J., Samuel Korecki hr. Pogoń (ok. 1586-1622), w Polski słownik biograficzny, t. 14, Wrocław 1968-1969, s. 60-62.

Majewski R., Cecora. Rok 1620, Warszawa 1970.

Mroczek G., Wychowanie syna w świetle testamentów Stanisława Żótkiewskiego, „Rocznik Przemyski” 53 (2017), z. 3: Historia, s. 19-34.

Niedźwiedź J., Nieśmiertelne teatra sławy. Teoria i praktyka twórczości panegirycznej na Litwie w XVII-XVIII w., Kraków 2003.

Nowicka-Struska A., Elementy teatralne, gest $i$ komunikacja niewerbalna $w$ siedemnastowiecznych kazaniach pogrzebowych, „Annales Universitatis Mariae Curie-Skłodowska. Sectio FF, Philologiae" 24 (2006), s. 71-97.

Podhorodecki L., Hetman Żółkiewski, Warszawa 1968.

Podhorodecki L., Wielki hetman Rzeczypospolitej. Opowieść o Stanisławie Żótkiewskim, Warszawa 1987.

Prochaska A., Hetman Stanisław Żółkiewski, Warszawa 1927.

Rok B., Druki załobne w dawnej Polsce XVI-XVIII w., w: Wesela, chrzciny i pogrzeby w XVI-XVIII wieku. Kultura życia i śmierci, red. H. Suchojad, Warszawa 2001, s. $187-201$.

Skwara M., Polskie drukowane oracje pogrzebowe XVII wieku. Bibliografia, Gdańsk 2009.

Sójka J., Pisarski Jan Stefan hr. Szreniawa (ok. 1630-1678), w: Polski słownik biograficzny, t. 26, Wrocław 1981, s. 549.

Trawicka Z., Jakub Sobieski 1591-1646. Studium z dziejów warstwy magnackiej w Polsce doby Wazów, Kraków 2007. 
Trawicka Z., Mowy weselne i pogrzebowe Jakuba Sobieskiego, w: Wesela, chrzciny i pogrzeby w XVI-XVIII wieku. Kultura życia i śmierci, red. H. Suchojad, Warszawa 2001, s. 173-186.

Tyszkowski K., Hetman Stanisław Żółkiewski, Lwów 1927.

Urwanowicz J., „Piis manibus”. Inskrypcje nagrobne rodu Żółkiewskich w XVII wieku, w: Cywilizacja prowincji Rzeczypospolitej szlacheckiej. Cykl 2: Nie wszystek umrę. Pamięć o zmarlych w kulturze staropolskiej, red. A. Jankowski, A. Klonder, Bydgoszcz 2015.

Urwanowicz J., „Początek i progres wojny moskiewskiej”, czyli o Stanisława Żółkiewskiego „ochocie do służenia królowi jegomości Rzeczypospolitej”, „Białostockie Teki Historyczne" 9 (2011), s. 55-65.

Urwanowicz J., Stanisław Żółkiewski wobec Moskwy. Koncepcje i działania, w: Polska wobec wielkich konfliktów w Europie nowożytnej. Z dziejów dyplomacji i stosunków międzynarodowych w XV-XVIII wieku, red. R. Skowron, Kraków 2009, s. 49-64.

Zasady wydawania tekstów staropolskich. Projekt, przykłady oprac. J. Woronczak, [red. nauk. M.R. Mayenowa przy współudz. Z. Florczak], Wrocław 1955.

Żurkowski S., Żywot Tomasza Zamojskiego kanclerza wielkiego koronnego, Lwów 1860.

\section{Opracowania wykorzystane przy opracowaniu aparatu naukowego edycji źródła}

Gawron P., Hetman koronny w systemie ustrojowym Rzeczypospolitej w latach 15811646, Warszawa 2010.

Grzybowski S., Jan Zamoyski, Warszawa 1994.

Hołd carów Szujskich, red. J. Chrościcki, M. Nagielski, Warszawa 2014.

Kaczorowski W., Bitwa pod Byczyna, Opole 1988.

Łaszczyńska O., Ród Herburtów w wiekach średnich, Poznań 1948.

Majewski W., Nalewajko Semen, w: Polski słownik biograficzny, t. 22, Wrocław 1977, s. $489-492$.

Olejnik K., Stefan Batory, Warszawa 2013.

Pismo Święte Starego i Nowego Testamentu w przekładzie z języków oryginalnych opracował zespół biblistów polskich $z$ inicjatywy benedyktynów tynieckich, red. nauk. A. Jankowski et al., przeł. W. Borowski et al., Poznań-Opole 2005.

Serczyk W.A., Na dalekiej Ukrainie. Dzieje Kozaczyzny do 1648 roku, Kraków 1984. Studia $z$ dziejów stosunków Rzeczypospolitej z Państwem Moskiewskim w XVI-XVII wieku, red. M. Nagielski, K. Bobiatyński, P. Gawron, Zabrze 2013.

Śliwiński A., Jan Zamoyski. Kanclerz i hetman wielki koronny, Warszawa 1947.

Urwanowicz J., Leczyć czy odcinać putrida membra? Stanisław Żółkiewski wobec Kozaków podczas powstania Nalewajki, w: Od Kijowa do Rzymu. Z dziejów stosunków Rzeczypospolitej ze Stolica Apostolska i Ukrainą, red. M.R. Drozdowski, W. Walczak, K. Wiszowata-Walczak, Białystok 2012, s. 103-116. 
Urzędnicy centralni i nadworni Polski XIV-XVIII wieku, oprac. K. Chłapowski et al., red. A. Gąsiorowski, Kórnik 1992.

Urzędnicy województwa ruskiego XIV-XVIII wieku (ziemie halicka, lwowska, przemyska, sanocka). Spisy, oprac. K. Przyboś, Wrocław 1987.

Wisner H., Zygmunt III Waza, Warszawa 2006.

Wójcik Z., Wojny kozackie w dawnej Polsce, Kraków 1989. 